\title{
Spatial and temporal dynamics of coffee-leaf-miner and predatory wasps in organic coffee field in formation
}

\author{
Dinâmica espacial e temporal do bicho-mineiro do cafeeiro e da vespa predadora em \\ plantação de café orgânico em formação
}

\author{
João Domingos Scalon ${ }^{\mathrm{I}^{*}}$ Maria Betania Lopes Avelar ${ }^{\mathrm{I}}$ Gabriela de Freitas Alves $^{\mathrm{I}}$ \\ Maurício Sérgio Zacarias ${ }^{\text {II }}$
}

\begin{abstract}
The coffee production is an economic mainstay for many countries in the world. Brazil is the world's largest producer and exporter of coffee, being responsible for about $25 \%$ of the world production. It is well known that coffee plantations are susceptible to more than 850 fungal and insect pests. Among these pests, the most important significant throughout Brazil is the coffee-leaf-miner, [Leucoptera coffeella (Guérin-Mèneville \& Perrottet, 1842) (Lepidoptera: Lyonetiidae)]. It is estimated that the loss in yield due to infestation by $\boldsymbol{L}$. coffeella moths can increase to as much as $80 \%$ in areas where the coffee-leaf-miner larvae are not controlled. Though it is effective, the chemical control of the pest substantially increases the cost of production and constitutes a risk to the environment. The knowledge about the spatialtemporal dynamics of coffee-leaf-miner and predatory wasps may provide valuable information about the biological management pest context. One way to investigate the spatialtemporal synchronism of predator and prey is to calculate and compare an index of spatial randomness within a sequence time. This paper advocates using the Morisita's index, coupled with the bootstrap method, in a temporal sequence to characterize the spatial-temporal dynamics of coffee-leaf-miner and predatory wasp (Hymenoptera: Vespidae) in one hectare of an organic coffee plantation. The results showed that coffeeleaf-miner and predatory wasps presented a seasonal behavior with a temporal synchronism. The results also showed that both new and preyed mines were aggregated during the peak population (dry season). There was little evidence for spacetime interaction between coffee-leaf-miner and predatory wasps.
\end{abstract}

Key words: Leucoptera coffeella, Hymenoptera: Vespidae, bootstrap, Morisita.

\section{RESUMO}

\begin{abstract}
A produção do café é, economicamente, muito importante para vários países do mundo. O Brasil é o maior produtor e exportador de café do mundo, sendo responsável por, aproximadamente, $25 \%$ da produção mundial. Sabe-se que as plantações de café são suscetíveis ao ataque de mais de 850 tipos de fungos e insetos. Entre essas pragas, a mais importante em todo Brasil é o bicho mineiro do cafeeiro [Leucoptera coffeella (Guérin-Mèneville \& Perrottet, 1842) (Lepidoptera: Lyonetiidae)]. Estima-se que a perda no rendimento devido à infestação do bicho mineiro pode chegar a $80 \%$ em plantações onde não existe controle da praga. Embora o controle químico seja eficaz para combatê-la, ele acarreta um aumento no custo da produção e constitui um risco para o meio ambiente. $O$ conhecimento da dinâmica espacial-temporal do bicho-mineiro e da vespa predadora (Hymenoptera: Vespidae) pode fornecer informações valiosas para o controle biológico da praga. Uma maneira de investigar o sincronismo espacial-temporal entre presa e predador é calcular algum índice para análise de completa aleatoriedade espacial e compará-lo ao longo do tempo. Este artigo sugere o uso do índice de Morisita, juntamente com o método bootstrap, em uma sequência temporal para caracterizar a dinâmica espacial-temporal do bicho-mineiro e da vespa predadora em um hectare de uma plantação orgânica de café. Os resultados revelaram que o bicho-mineiro e a vespa predadora apresentaram um comportamento sazonal com um sincronismo temporal. Além disso, observou-se que minas novas e predadas apresentavam agrupamentos durante a estação mais seca do ano. Existem poucas evidências de interação espaço-temporal entre minas predadas e vespas predadoras.
\end{abstract}

Palavras-chave: Leucoptera coffeella, Hymenoptera: Vespidae, bootstrap, Morisita.

'Departamento de Ciências Exatas, Universidade Federal de Lavras (UFLA), CP 3037, 37200-000, Lavras, MG, Brasil. E-mail: scalon@dex.ufla.br. *Autor para correspondência.

IIEMBRAPA Café, Empresa de Pesquisa Agropecuária de Minas Gerais (EPAMIG), Lavras, MG, Brasil. 


\section{INTRODUCTION}

Coffee (Coffea sp.) grows over seventy countries, and therefore is one of the most important crops in the world. Coffee production, with an annual estimated retail value of over US\$ 70 billion, is surpassed only by oil. Brazil is the leading country in this activity, being responsible for, at about, $25 \%$ of the world coffee production (LEWIN et al., 2004).

Two species of coffee (Coffea arabica L. and Coffea canephora Pierre \& Froehner, also known as Robusta), are commercially traded, with $\boldsymbol{C}$. arabic . comprising approximately $65 \%$ of coffee production (LEWIN et al., 2004). It is well known that both species are susceptible to fungal and insect pests REIS et al. (2006). Among these pests, one of the most important significant throughout Brazil is the coffee-leaf-miner [Leucoptera coffeella (Guérin Mèneville \& Perrottet, 1842) (Lepidoptera: Lyonetiidae)].

The caterpillars of the leaf miner moth attack the coffee leaves causing loss of the photosynthetic area as a consequence of necrosis of the leaf surface and early fall of the coffee leaf. This may affect the coffee plant crop in many different ways. Firstly, the plant will have a life spam shorter than expected, secondly there is a reduction of the plant production, where it is estimated that the loss in yield due to infestation by L. coffeella moths is around $40 \%$ in Brazil, and thirdly there is a drop in the quality of the coffee beans (COFFEE-TEA.CO.UK, 2010).

The conventional chemical control is the method most used against the coffee-leaf-miner, unfortunately this method leads to many side effects: It does not prevent occurrence of secondary outbreaks, the pest may become resistant to the insecticides that are used to control it and the pesticide may be lethal to natural predators of the coffee-leaf-miner. Thus, chemical control is not a good long term strategy for the control of coffee pests (COFFEE-TEA.CO.UK, 2010). Consequently, coffee producers are being trained in organic practices to develop free insecticide practices. REIS et al. (2006) advocate that predatory wasps play a significant role in the natural biological control of the coffee-leaf-miner. Some species of predators of the coffee-leaf-miner found in Brazil and pertaining to the Hymenoptera order and the Vespidae family are Brachygastra lecheguana (Latreille, 1824), Polistes versicolor (Oliver, 1791), Polybia paulista Ihering, Polybia scutellaris (White, 1841) and Protonectarina sylveirae (Saussure, 1854) (REIS et al., 2006).

It is well known that biological variables show often an important spatial heterogeneity and, therefore, the knowledge about insects spatial distribution is essential in order to provide an integrated pest management (BACCA et al., 2006). Also, the apparent existence of temporal clusters of high incidence in many crop pests suggests that the temporal distribution of these pests might be influenced by environmental and weather factors (KREBS, 1999). Thus, basic knowledge about the spatial-temporal dynamics of the coffee-leaf-miner and a generalist predator (predatory wasp) could contribute to the efficiency of the development of organic management in coffee plantations.

One way to investigate the spatio-temporal synchronism of predator and prey is to calculate and compare indices of spatial randomness in a temporal sequence. If a series of counts of the number of individual animals are taken in some areas of defined size and shape then there are available many indices of spatial aggregation. KREBS (1999) advocates that the Morisita's index is the best one in this purpose and, therefore this index has been frequently used by researchers for pest spatial analysis of . Unfortunately, there are certain objection about how they are using it. Namely, how to assess the sampling variation associated with an index calculated from sample data. Without this, it is not possible to obtain confidence interval for the population index and the analysis is based only on point estimates that are often subjective.

The aim of this paper is to present a distribution-free method based on an application of bootstrap method to obtain confidence intervals of Morisita's index, in a temporal sequence, in order to characterize the spatial-temporal dynamics of the coffee-leaf-miner (L. coffeella) and predatory wasps (Hymenoptera: Vespidae) in a plantation of organic coffee.

\section{MATERIAL AND METHODS}

The study was conducted between January 2005 and March 2007 at the Cachoeira Farm, in Santo Antonio do Amparo county, MG, Brazil (2053' 54.29', $\mathrm{S}, 44^{\circ} 56^{\prime} 29.87^{\prime}$ ' $\mathrm{W}$, altitude $\left.1,013 \mathrm{~m}\right)$. This region presents annual average temperature of $19^{\circ} \mathrm{C}$, annual average precipitation of $1,529 \mathrm{~mm}$ and average relative humidity of $76 \%$. Throughout this paper, "rainy season" refers to the period between November and March when historical average rainfall is $>200 \mathrm{~mm}$ and the historical average temperature is approximately $24^{\circ} \mathrm{C}$, while "dry season" refers to the April and October period when average rainfall is $<100 \mathrm{~mm}$ and the historical average temperature is approximately $10^{\circ} \mathrm{C}$. Dimensions of the experimental area were $120 \mathrm{~m}$ by $90 \mathrm{~m}$. The whole field was planted with a two-year old plantation of coffee (C. arabic.) with $0.5 \mathrm{~m}$ between plants and $4.5 \mathrm{~m}$ between rows. An approximately regular grid was designed and situated over the 
experimental area, resulting in a total of 35 sampling unit areas with, approximately, $1.5 \times 1.5 \mathrm{~m}$ formed by one or two plants.

At each node of the grid, samples of ten leaves were taken from the canopy of the coffee plants. The population data were based on monthly catches in the 35 sampling points. After collection, the coffee leaves were transferred to the laboratories of the "Empresa de Pesquisa Agropecuária de Minas Gerais (EPAMIG)", Lavras, MG for analyses. The number of both new and preyed mines was taken from the ten leaves. Additional to these two variables, yellow rectangular adhesive sticky traps were used to capture the predatory wasps. The traps were fastened in stakes close to the coffee plants rows at a height of $0.5 \mathrm{~m}$ above the soil. The predatory wasps captured in the traps were identified and recorded at the laboratories of EPAMIG one week after placing the traps.

The $y_{1}, y_{2}, \ldots ., y_{35}$ are the counts of individuals (new mines, number of preyed mines and predatory wasps) from the sampling units. MORISITA (1962) proposed an dispersion index for analyzing spatial distribution on various spatial scales estimated by, $I_{\delta}=\frac{n \sum_{i=1}^{n} y_{i}\left(y_{i}-1\right)}{n \bar{y}(\bar{y}-1)}$ where $\bar{y}$ is the sample mean.
The bootstrap method was used in order to construct confidence intervals for the Morisita's index. In this method, new (bootstrap) samples, each of the same size as the observed original sample are drawn, with replacement, from the observed original sample. The Morisita's index is first calculated using the observed original sample, and then recalculated using each of the new samples, yielding a bootstrap distribution. This resulting distribution can be used to make inferences about the parameter. The researchers adopted the $5 \%$ and $95 \%$ percentiles of the bootstrap distribution to get the $90 \%$ standard confidence interval. It was also adopted a number of bootstrap samples equal to 1,000 which is the recommended for estimating percentiles (EFRON \& TIBSHIRANI, 1993). All methods described in this section have been implemented using the software $R$ (R DEVELOPMENT CORE TEAM, 2009).

\section{RESULTS}

Figure 1 summarizes the results of the exploratory data analysis using classical descriptive statistics and shows monthly average counts of new mines, preyed mines and predatory wasps in the thirtyfive sampling points. Figure 2 presents the spatial-

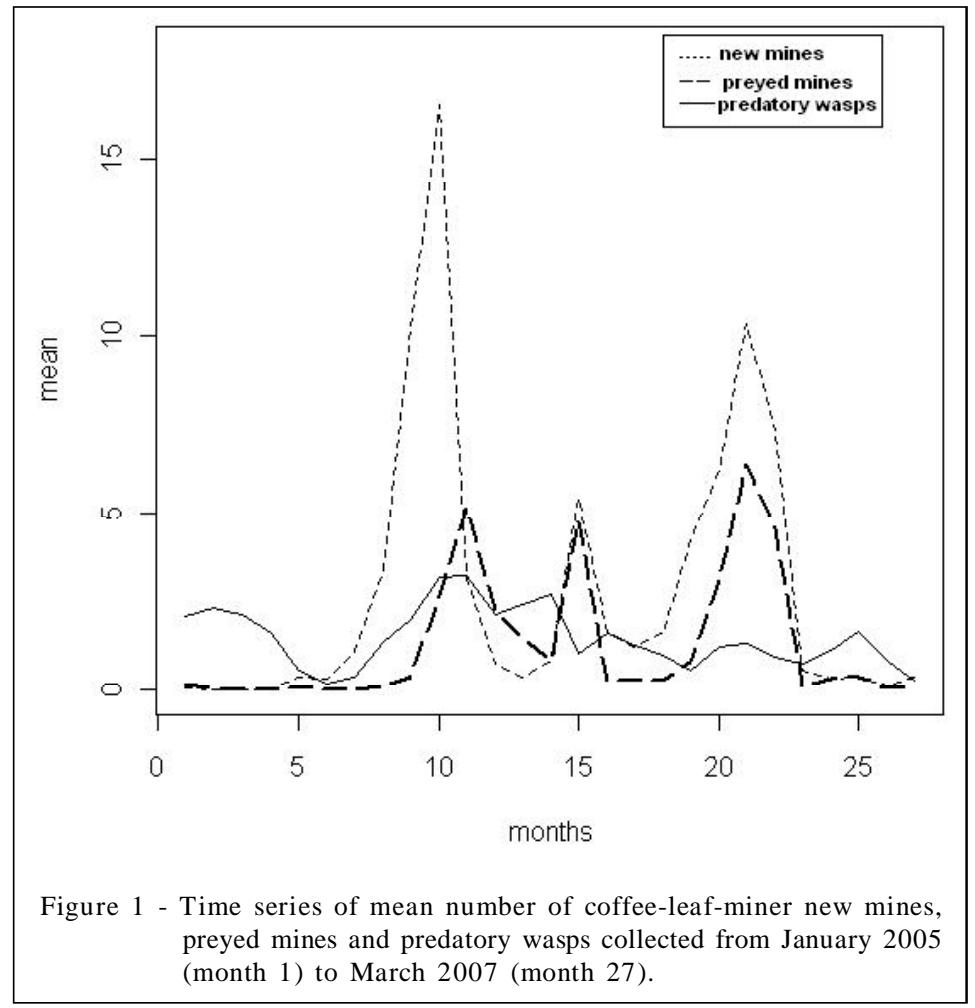

Ciência Rural, v.41, n.4, abr, 2011. 


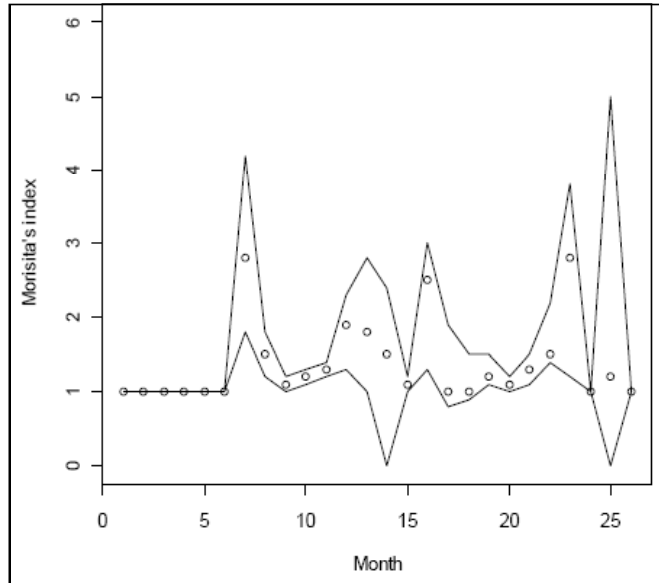

(A)

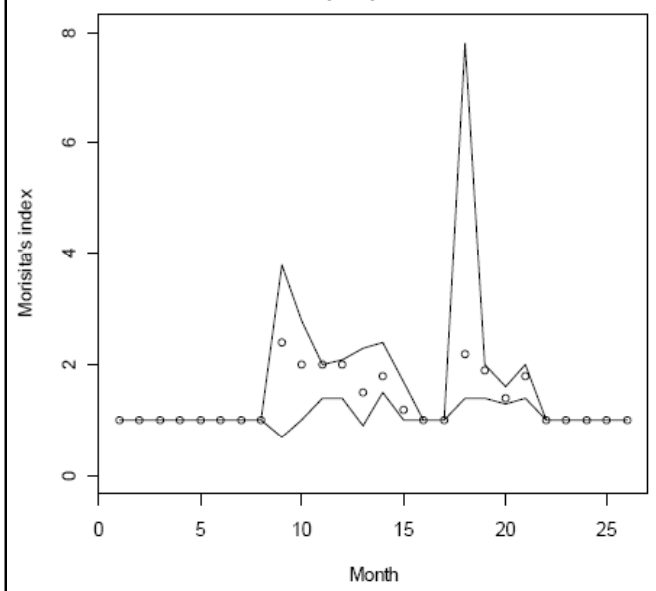

(B)

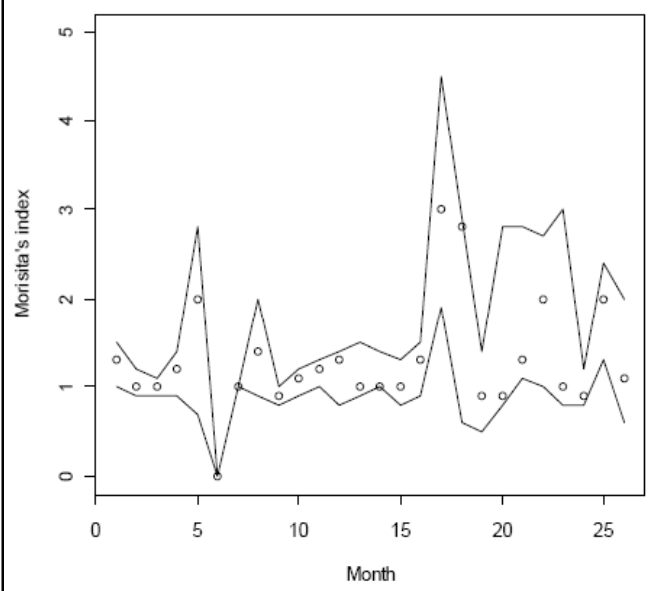

(C)

Figure 2 - Morisita's index of dispersion (small circles) for new mines (A), preyed mines (B) and predatory wasps $(\mathrm{C})$. Solid lines are twotailed $90 \%$ confidence intervals from 1000 bootstrap samples. Data collected from January 2005 (month 1) to March 2007 (month 27). temporal analysis and shows the Morisita's index of dispersion together with the two-tailed $90 \%$ bootstrap confidence intervals. The point estimates show Morisita's index higher than one for the majority of the months for all variables and, therefore showed that there is evidence for rejecting the hypothesis of randomness in favor of an aggregated alternative. Figures 1 and 2 show strong evidences that predatory wasps, new and preyed mines interactions are not static but temporally and spatially dynamic. Figures 1 and 2 also show almost no evidence for space-time interaction for those variables in the organic coffee plantation.

This study identified a total of 14 species of wasps (Hymenoptera: Vespidae). It was identified three species that presented significantly positive correlation with the number of preyed mines: Brachygastra augusti (Saussure, 1854) $(\mathrm{R}=0.76, \mathrm{P}<0.01)$ Polybia occidentalis (Olivier, 1791) $(\mathrm{R}=0.53, \mathrm{P}<0.01)$ and $\boldsymbol{P}$. paulista $(\mathrm{R}=0.43$, $\mathrm{P}=0.04)$. Wasps were responsible for killing from $25 \%$ to $50 \%$ of all larvae.

\section{DISCUSSION}

Several insect pests have been reported in coffee plantations and the most important one is the coffee-leaf-miner (L. coffeella). One of the challenges in organic coffee production is the control of the pest outbreaks without the use of pesticides. An attempt to control the pest in organic coffee is to use its natural enemies such as parasitoids and predatory wasps. Thus, Brazilian researchers have made a continous effort to improve the efficiency of pest control in organic coffee plantations by using some of these biological organisms.

It is accepted that interaction between predators and their prey can only be understood within a spatially explicit context. STEINBERG \& KAREIVA (1997) argue that the lack of spatially explicitly, large scale spatial pattern field studies is identified as a major obstacle to the understanding of fundamental ecological processes.

It is observed in figure 1 that the mean number of new mines and preyed mines presented peaks in the final driest periods, that is, in October 2005 (month number 10) and September 2006 (month 21). Low averages are observed in rainy seasons. The presence of a peak in March 2005 (month 15) is due the occurrence of a particular weather condition called "small summer" in that year. Figure 1 shows that the dry conditions and high temperatures observed in the small summer increased the infestation level of coffeeleaf-miner in the middle of the rainy season in February 
(month 14). Thus, it is very clear that the number of both new and preyed mines presented a seasonal behavior. Actually, these two variables presented a clear temporal synchronism. It was expected this seasonal behavior once the coffee-leaf-miner does better in dry conditions. Under wet conditions, plants have very low infestation levels of coffee-leaf-miner because of water entering the mine and drown the larvae (VEGA et al., 2006). These results show that seasonal variation in weather variables, such as rainfall and temperature may be the most important causes of changes in insect abundance. Previous studies have addressed the influences of environmental (rainfall, relative humidity, ambient temperature, etc.) on coffeeleaf-miner population dynamics (REIS et al., 2006; PEREIRA et al., 2007, LOMELÍ-FLORES, 2010). For example, PEREIRA et al. (2007) have suggested that heavy rain was the main source of coffee-leaf-miner mortality, particularly during the rainy season. The number of predatory wasps showed some periodicity but no obvious temporal synchronism with the other variables.

Figure 1 also shows the significant role played by the predatory wasps in the natural biological control of the coffee-leaf-miner. Studies have showed that some species of predators of the coffee-leaf-miner pertaining to the Hymenoptera order and the Vespidae family are $\boldsymbol{P}$. sylveirae, Protopolybia sp., P. paulista, $\boldsymbol{P}$. occidentalis, $P$. scutellaris, B lecheguana, Synoeca surinama cyanea (Fabr., 1775) e Polistes sp. (REIS et al., 2006). This research showed that wasps were responsible for killing from $25 \%$ to $50 \%$ of all larvae.

It was identified three species that presented significantly positive correlation with the number of preyed mines: Brachygastra augusti (Saussure, 1854), $\boldsymbol{P}$. occidentalis and $\boldsymbol{P}$. paulista. It was observed that only the $\boldsymbol{B}$. augusti has never been reported as predator of the coffee-leaf-miner. This may be due to three different reasons. Firstly, a sort of some identification mistake since it is very similar to the B. lecheguana; secondly $\boldsymbol{B}$. augusti occurs in low populations (as in the present study) and therefore it is not ease to collect it, and thirdly there is a possibility that B. augusti is more adapted than others to the environment of the coffee plantation in formation. Four species of wasps (Agelaia multipicta (Haliday, 1836), Polybia fostidiosuscula (Saussure, 1854), Polybia ignobilis (Haliday, 1936) and $\boldsymbol{P}$. silveirae) were relatively abundant during the study period, but they did not present a significant correlation with the number of preyed mines. Although the number of new mines presents oscillations during the period of population peaks, the number of preyed mines was practically constant during those periods. This may happen because the predatory wasps may not achieve population numbers high enough to significantly decrease the pest population.

Figure 2 shows the Morisita's index together with the two-tailed $90 \%$ bootstrap confidence intervals. The interpretation of the bootstrap confidence interval plots is straightforward. If the number one lies between the confidence limits, it suggests acceptance of the null hypothesis of randomness distribution of the variable over the study region. If the number one lies below the lower confidence limit, it provides evidence for rejection of the hypothesis of randomness of the variable in favor of an aggregated alternative. If the number one lies above the upper confidence limit, it provides evidence for rejection of randomness of the variable in favor of a regular alternative. It is observed in figures $2 \mathrm{~A}$ and $2 \mathrm{~B}$ that the number one lies below the lower confidence limit for the majority of the months for the counts of new and preyed mines, suggesting that it can be $90 \%$ confident for the rejection of the null hypothesis of randomness distribution in favor of an aggregated alternative of these variables over the study region. It was not observed presence of regular distribution statistically significant for these variables. Figure $2 \mathrm{C}$ indicates a slight tendency toward an aggregated pattern for the number of predatory wasps. It was observed that, in general, the hypothesis of randomness was accepted in those cases where the counts were close to zero.

Some studies have rejected the hypothesis of spatial randomness distribution in favor of an aggregated alternative of coffee-leaf-miner (BACCA et al., 2006). In this paper the evaluation of the spatial distributions of coffee-leaf-miner and wasps throughout the months was carried out using Morisita's index of dispersion. Although, the Morisita's index has been used extensively in ecology, it has recently come under criticism. The use and misuse of this index have been discussed and debated by PERRY (1998). One of these criticisms is that Morisita's index requires that quadrats need to be small in relation to the pattern scale described. This aspect is not really a problem in our study, once the quadrat areas are very small $(1.5 \times 1.5 \mathrm{~m})$ comparing to the scale of the coffee plantation (1ha).

The authors add another criticism which is related to the use of point estimates of the index instead of confidence intervals. It is well know that the point estimate depends on which sample is selected. Different samples generally yield different estimates, due to sampling variability. While the point estimate index represents the best guess for the population index, it is 
not the only plausible value. Thus, instead of reporting a point estimate as the single most credible value for the population index, this research report an interval of reasonable index values based on the sample data. It was presented a distribution-free method based on the bootstrap method to obtain confidence interval for testing the hypothesis of randomness. The analysis based on Morisita's index together with the two-tailed $90 \%$ bootstrap confidence intervals showed evidence for clustering of number of predatory wasps, new and preyed mines.

Although the results provided by the Morisita's index coupled with the bootstrap method have characterized the distribution patterns of predatory wasps, new and preyed mines, examination of the plots in figure 2 suggests weak evidence for spatial synchronism among these variables in the organic coffee plantation. This research suggests some hypothesis about this lack of spatial-temporal synchronism. Availability of alternative food sources for the wasps may reduce the probability of spatial synchronism of coffee-leaf-miner and wasps in the plantation. For example, wasps feed on immature stages of several other arthropods which are plenty available in the coffee plantation and in the forests nearby (REIS et al., 2006). The relationship between wasps and coffee-leaf-miner may also be dependent upon environmental factors. These factors have been pointed out as potential to cause imperfect spatialtemporal synchronism of predator-prey in many species (PARK \& OBRYCKI, 2004). This is absolutely true in organic plantations once organic coffee producers are restricted from using pesticides and depend upon soil management techniques to provide nutrients to their coffee crop and environmental and meteorological factors to control the presence of pests. The authors argue is that a higher (or a lower) density of new mines in the coffee plantation comparing to the density of wasps may also reduce the probability of spatial synchronism.

It was observe that besides the relative humidity, there are other meteorological factors that may cause important variation in insect catches such as temperature, direction and intensity of winds and consequently in the spatial-temporal behavior (LOMELÍ-FLORES, 2010). Unfortunately, there is no available specific data of these variables and therefore it was not possible to measure the influence of these meteorological factors in the spatial-temporal dynamics of coffee-leaf-miner and wasps.

Finally, this paper documents an alternative distribution-free method based on bootstrap for obtaining confidence intervals for the population
Morisita's index of dispersion that may be useful for studying prey-predator dynamics through the evolution of spatial structure in time. Evidently, the method should be extendable to the estimation of other ecological indices such as variance-to-mean ratio, $k$ of the negative binomial, Green's coefficient and distance methods.

\section{CONCLUSION}

The application of the Morisita's index, coupled with the bootstrap method, in a temporal sequence proved to be a powerful tool to characterize the spatial-temporal dynamics of insects. The method was applied in data from an organic coffee plantation in formation and provided evidences that: (a) coffeeleaf-miner (Lepidoptera: Lyonetiidae) and predatory wasps (Hymenoptera: Vespidae) present a seasonal behavior with a temporal synchronism; (b) New and preyed mines are aggregated during the peak population (dry season) and, (c) Coffee-leaf-miner and predatory wasps present little evidence for space-time interaction.

\section{ACKNOWLEDGEMENTS}

This study was funded by Fundação de Amparo à Pesquisa do Estado de Minas Gerais (FAPEMIG) (Grant CEX APQ-1643-5.01/07) and CBP\&D Café. The researchers are grateful to the owners of the Cachoeira Farm for providing free access to the plantation field. G. F. A. thanks CAPES for the scholarship. The authors are indebted to the two referees and the two editors for their constructive comments and suggestions that substantially improved the presentation of this article.

\section{REFERENCES}

BACCA, T. et al. Optimum spacing of pheromone traps for monitoring the coffee-leaf-miner Leucoptera coffeella. Entomologia experimentalis et applicata, v.119, p.39-45, 2006. Available from: <http://onlinelibrary.wiley.com/doi/ 10.1111/j.1570-7458.2006.00389.x/abstract>. Accessed: Jan 15, 2009. doi: 10.1111/j.1570-7458.2006.00389.x.

COFFEE-TEA.CO.UK. Coffee leafminer (Leucoptera coffeella). 2010. Available from: 〈http://coffee-tea.co.uk/leafminer.php>. Accessed: Oct 20, 2010 .

EFRON, B.; TIBSHIRANI, R.J. An introduction to the bootstrap. New York: Chapman and Hall, 1993. 456p.

KREBS, C.V. Ecological methodology. 2.ed. New York: Benjamin Cummings, 1999. 624p.

LEWIN, B. et al. Coffee markets: new paradigms in global supply and demand. Washington, DC: World Bank Agriculture and Rural Development, 2004. 150p. (Discussion Paper n.3). Available from: <http://papers.ssrn.com/sol3/papers.cfm?abstract_id=996111>. Accessed: Jan 22, 2010. 
LOMELÍ-FLORES, J.R. et al. Impacts of weather, shade cover and elevation on coffee leafminer Leucoptera coffeella (Lepidoptera: Lyonetiidae) population dynamics and natural enemies. Crop Protection. v.29, p.1039-1048, 2010. Available from: <http://www2.tap-ecosur.edu. mx/mip/pdf/>. Accessed: Oct 2, 2010. doi: 10.1016/ j.cropro.2010.03.007.

MORISITA, M. Id-index, a measure of dispersion of individuals. Researches on population ecology, v.4, p.1-7, 1962. Available from: <http://meme.biology.tohoku.ac.jp/POPECOL/ RP\%20PDF/4/pp.1.pdf>. Accessed: Dec 14, 2008.

PARK, I.; OBRYCKI, J.J. Spatio-temporal distribution of corn leaf Aphids (Homoptera: Aphididae) and lady beetles (Coleoptera: Coccinellidae) in Iowa cornfields. Biological control, v.31, p.210-217, 2004. Available from: <http:// www.sciencedirect.com>. Accessed: Jul 11, 2010. doi:10.1016/ j.biocontrol.2004.06.008.

PEREIRA, E.J. et al. Seasonal mortality factors of the coffee leafminer, Leucoptera coffeella. Bulletin entomological research, v.97, p.421-432, 2007. Available from: <ht p ://journals.cambridge.org/action/ display Abstract? fromPage $=$ online $\&$ aid $=1210024>$. Accessed: Jan 6, 2011. doi: 10.1017/S0007485307005202.

PERRY, J.N. Measures of spatial pattern and spatial association for counts and insects. In: BAUGARTNER, J. et al. (Eds.). Population and community ecology for insect management and conservation. Rotterdam: Balkerma, 1998. 253p.

R DEVELOPMENT CORE TEAM. R: a language and environment for statistical computing. Vienna: $R$ Foundation for Statistical Computing, 2009. Available from: <www.r-project.org>. Accessed: Feb 15, 2009.

REIS, P.R. et al. Alerta para o bicho-mineiro. Cultivar, v.8, p.13-16, 2006.

STEINBERG, K.P.; KAREIVA, P. Challenges and opportunities for empirical evaluation of spatial theory. In: TILMAN D.; KAREIVA, P. (Eds.). Spatial ecology. Princeton: Princeton University, 1997. 416p.

VEGA, F.E. et al. Coffee insects: ecology and control. In PIMENTEL, D. (Ed.). Encyclopedia of pest management. London: Marcel Dekker, 2006. 929p. 